\title{
RANGE EXPANSION OF A LOCALLY ENDANGERED MUSTELID (EIRA BARBARA) IN SOUTHERN MEXICO
}

\author{
Fernando Ruiz-Gutiérrez ${ }^{1}$, Enrique Vázquez-Arroyo ${ }^{1}$, and Cuauhtémoc Chávez ${ }^{2}$
}

\begin{abstract}
We documented the occurrence of Eira barbara in the municipalities of Tecpán de Galeana and Petatlán, state of Guerrero, Mexico. Our records represent a 450-km range expansion from the most recent northern occurrences of this species in the Mexican Pacific coast states.
\end{abstract}

Resumen.-Se documentó la presencia del viejo de monte (Eira barbara) en los municipios de Tecpán de Galeana y Petatlán, Guerrero, México. Estos registros representan un aumento de su área de distribución al norte en 450-km de los registros más recientes de la especie en la costa del Pacífico Mexicano.

The tayra (Eira barbara) is a medium-sized mustelid listed as endangered by Mexican law (NOM-059-SEMARNAT-2010; Official Journal of the Federation 2010). It is a widely distributed species occurring from sea level to 2600 masl, being historically present from Mexico to Argentina (Presley 2000, Chávez 2014) but having several information gaps about its ecology (Emmons and Freer 1990, Brooks 1993). Populations in its northernmost distribution (i.e., many areas of Mexico) have been the least studied (López-González and Aceves 2007). On the northern Pacific Slope of Mexico, only a single record has been reported in Sinaloa in 1904 by Allen (1906). South of Sinaloa, there is an absence of tayra records in several Mexican states of the Pacific coast region: Nayarit, Jalisco, Colima, Michoacán, and Guerrero. It is therefore hypothesized that the 2 young individuals collected at low elevation in Sinaloa (Allen 1906) probably stemmed from an introduction (Álvarez-Castañeda 2000), since most samples from the Pacific Slope of Mexico have been recorded in Oaxaca and Chiapas (Pérez-Irineo and SantosMoreno 2010, Chávez 2014, Espinosa-Lucas et al. 2015; Fig 1.) at altitudes higher than 2000 masl (Chávez 2014). In the state of Guerrero there are museum records from Acahuizotla (1957) at the mammal collection of the Biodiversity Research and Teaching Collection, Texas A\&M University, College Station (López-Wilchis and López-Jardines 1999).
Due to limited knowledge and lack of current records, the specific objective of this paper is to provide information on recent records of tayra, especially in areas where the species was previously assumed absent or at a very low probability of occurrence.

Field sampling was conducted in 2 municipalities in the state of Guerrero, Tecpán de Galeana and Petatlán (2258 masl), in the tropical lowlands of the Mexican Pacific coast. These areas are characterized by humid tropical weather, with summer rainfall and intermittent rainfall in other seasons. The predominant vegetation types are tropical semievergreen forest, tropical deciduous forest, semideciduous forest, oak forest, pine forest, and pine-oak forest associations; cloud forest is present at 1000 to $2000 \mathrm{~m}$ asl and in areas with greater humidity (Werre and Estrada 1999).

The information presented in this note comes from one of several projects conducted during 2009-2014 in the state of Guerrero, with different sampling efforts by camera trapping. Three individuals were photographed as a result of a sampling effort of 6096 camera trap days. In addition, a specimen (skeleton) was collected and deposited at the Colección Nacional de Mamíferos (= National Collection of Mammals) at the Instituto de Biología, Universidad Nacional Autónoma de México $(=$ Biology Institute, National Autonomous University of Mexico [UNAM]). Also, the vegetation type, altitude, and geographical

${ }^{1}$ Laboratorio Integral de Fauna Silvestre, Unidad Académica de Ciencias Químico Biológicas, Universidad Autónoma de Guerrero, Av. Lázaro Cárdenas S/N Col. La Haciendita, Ciudad Universitaria, Chilpancingo, Guerrero, México, 39087.

${ }^{2}$ Corresponding author. Departamento de Ciencias Ambientales, División de Ciencias Biológicas y de la Salud, Universidad Autónoma Metropolitana-Unidad Lerma, Av. Hidalgo poniente 46, Col. La Estación, Lerma de Villada, Estado de México, 52006, México. E-mail: j.chavez@correo.ler.uam.mx 


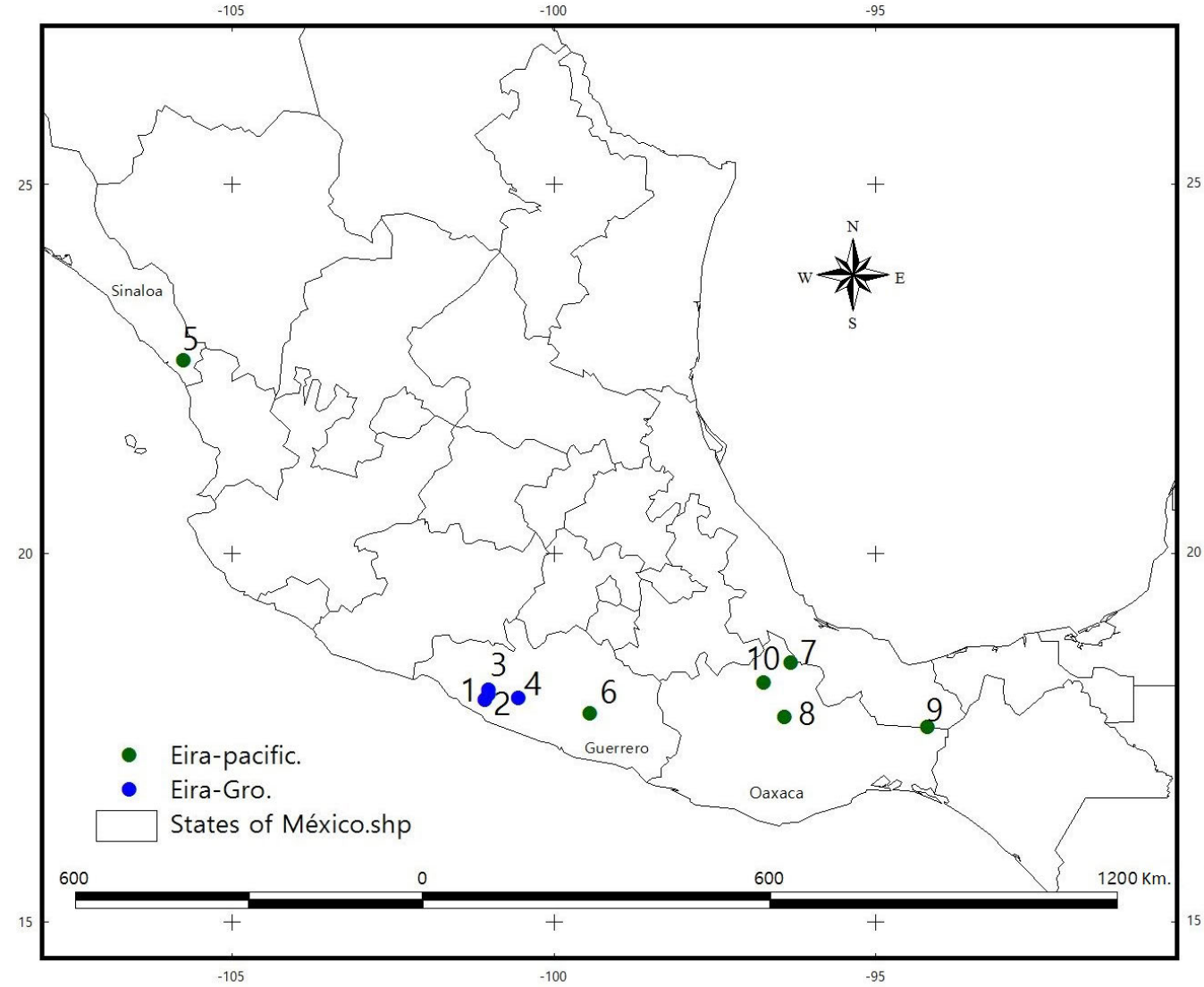

Fig. 1. Records of Eira barbara on the Pacific Slope (Sinaloa to Oaxaca), Mexico. Guerrero: (1) Petatlán-La Soledad*, 1 km NE; (2) Petatlán-Banco Nuevo*, 3 km NE; (3) Petatlán-La Ceiba*; (4) Tecpan de Galeana-Cordón Grande*; (6) Chilpancingo-Acahuizotla (1957). Sinaloa: (5) Escuinapa (1904; Allen 1906). Oaxaca: (7) Tuxtepec-San Miguel Soyaltepec (before 2010; Pérez-Irineo and Santos-Moreno 2010); (8) Ixtlán-Capulalpam (before 2008; Cruz-Espinoza et al. 2012); (9) Chimalapas-La Fortaleza (2009-2010; Lira-Torres and Briones-Salas 2012); (10) Santa María Pápalo (2012; Espinosa-Lucas et al. 2015). Asterisks indicate records from this study.

coordinates were recorded at each camera trap station.

The information obtained from the fieldwork was complemented by records from the vertebrate collections of the Texas Cooperative Wildlife Collection (TCWC; now the Texas A\&M Biodiversity Research and Teaching Collections), which are available online in the databases of the Comisión Nacional para el Conocimiento y Uso de la Biodiversidad (= National Biodiversity Information System of the National Commission on Knowledge and Use of Biodiversity [CONABIO]).

Our records of $E$. barbara represent the most recent evidence of the species' presence in the state of Guerrero. Our photographs constitute 3 records in the Mexican Pacific coastal state in a region where the tayra has never been documented (Fig. 1). On 23 June 2009 , the skeletal remains of a male tayra (National Collection of Mammals: CNMA47868) were collected in the community of $\mathrm{La}$ Ceiba, municipality of Petatlán, Guerrero, in a pine-oak forest $\left(17^{\circ} 43^{\prime} 16.9^{\prime \prime} \mathrm{N}, 101^{\circ} 2^{\prime} 46.9^{\prime \prime} \mathrm{W}\right.$; $1252 \mathrm{~m}$ asl) (locations of records are shown in Fig. 1; Table 1). The individual died presumably due to attacks by dogs owned by residents. In May 2011, two female tayras were photographed by camera traps (Cuddeback ${ }^{\circledR}$, Digital Expert $3 \mathrm{mp}$, Green Bay, WI), at a site located about $1 \mathrm{~km}$ NE of La Soledad. The vegetation type in the area is semideciduous tropical forest interspersed with coffee trees $\left(17^{\circ} 34^{\prime} 24^{\prime \prime} \mathrm{N}\right.$, $101^{\circ} 06^{\prime} 02^{\prime \prime} \mathrm{W}$; $\left.1151 \mathrm{masl}\right)$. Another individual was captured by camera traps $3 \mathrm{~km} \mathrm{NE}$ of Banco Nuevo, in an area dominated by pine 
forests $\left(17^{\circ} 39^{\prime} 23^{\prime \prime} \mathrm{N}, 101^{\circ} 02^{\prime} 12^{\prime \prime} \mathrm{W} ; 1291 \mathrm{masl}\right)$. Both records were made in Petatlán. On 7 March 2014, one male specimen was photographed in the ejido (communal land tenure in Mexico) Cordón Grande, municipality of Tecpán de Galeana, Guerrero $\left(17^{\circ} 35^{\prime} 47^{\prime \prime} \mathrm{N}\right.$, $100^{\circ} 34^{\prime} 47^{\prime \prime} \mathrm{W} ; 2258 \mathrm{~m}$ asl). The dominant vegetation type is pine-oak forest. All records consisted of adult individuals, captured at 17:34, 12:35 and 19:02, respectively (Fig. 2). It was possible to identify at least 2 individuals by camera trapping, due to the distinct color patterns of their heads.

The nearest records for the species were obtained in 2008 at Capulalpam de Méndez, Ixtlán (Cruz-Espinoza et al. 2012), Tuxtepec (Pérez-Irineo and Santos-Moreno 2010), and Santa María Pápalo in 2012, all of which are in the state of Oaxaca (Table 1; Espinosa-Lucas et al. 2015).

There are additional museum records of 2 females collected in 1957 and deposited with the mammal collection at TCWC (catalog number 5865). These records represent skeletons recovered at Acahuizotla (Fig. 3; Table 1).

Our records have confirmed the presence of E. barbara in Guerrero thereby increasing its geographic distribution more than $170 \mathrm{~km}$ from the nearest historic record of Acahuizotla and $450 \mathrm{~km}$ from Santa María Pápalo, Oaxaca (Espinosa-Lucas et al. 2015). There are no published records in Sinaloa, Nayarit, Jalisco, Colima, or Michoacán, as reported by ÁlvarezCastañeda (2000); and E. barbara is not included on systematic lists of mammals of Michoacán (Monterrubio-Rico et al. 2014) or Jalisco (Godínez et al. 2011). Therefore, the tayra records presented in this paper represent the northernmost records.

We believe our tayra records in Banco Nuevo and Cordón Grande are especially significant because this species had not been previously recorded in pine forest or pine-oak forest an altitude higher than 2000 masl in Mexico (Chávez 2014).

The tayra is considered by Mexican law as endangered, mainly due to habitat loss and fragmentation (NOM-059-SEMARNAT-2010; Official Journal of the Federation 2010, Chávez 2014). Eira barbara is a species mainly found in habitats with minimal disturbance, although it has rarely been recorded in secondary forests, fragmented gallery forest, and agricultural areas. Tayras may be attracted to the 


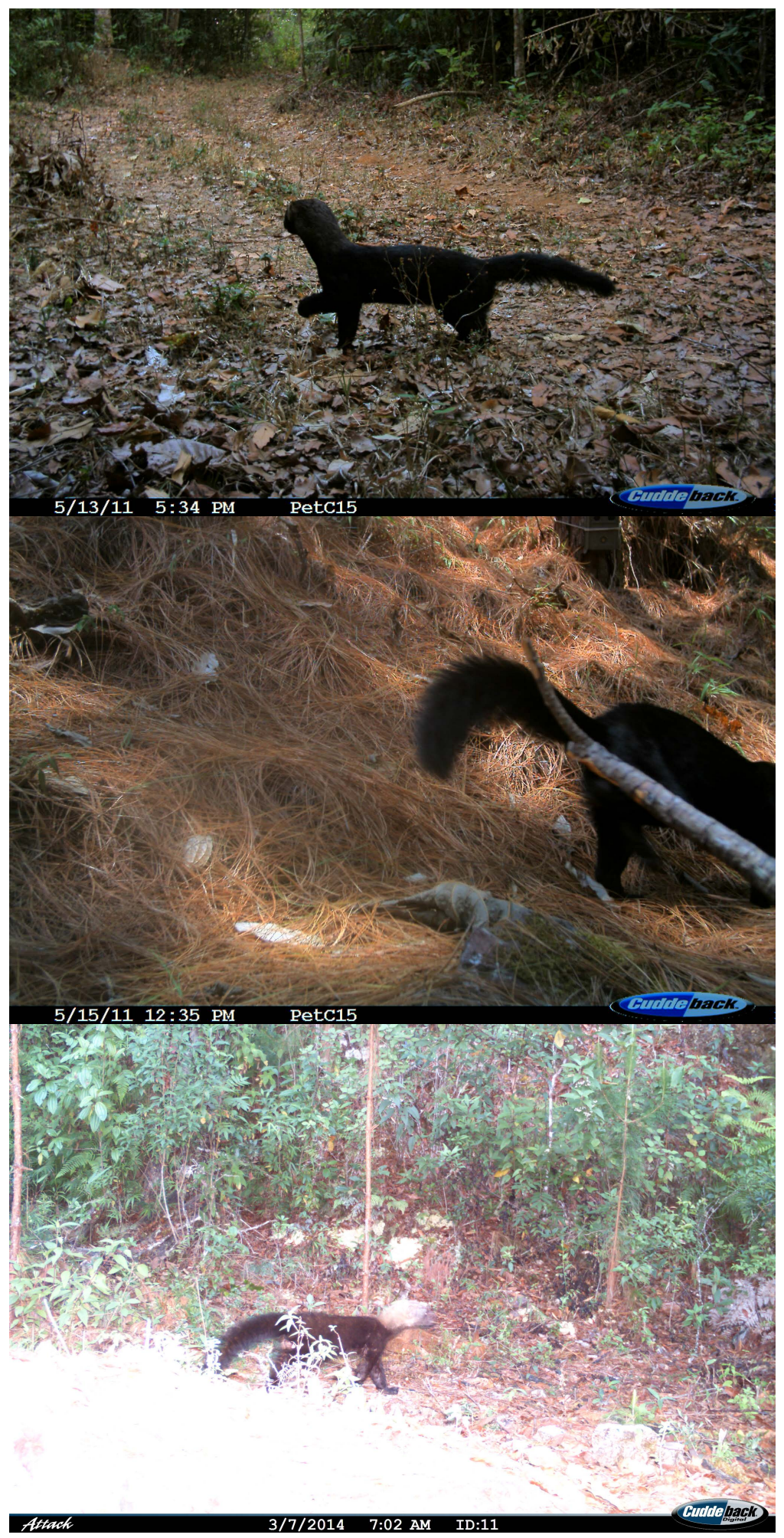

Fig. 2. Images of tayras (Eira barbara) obtained by camera traps in the study area. 


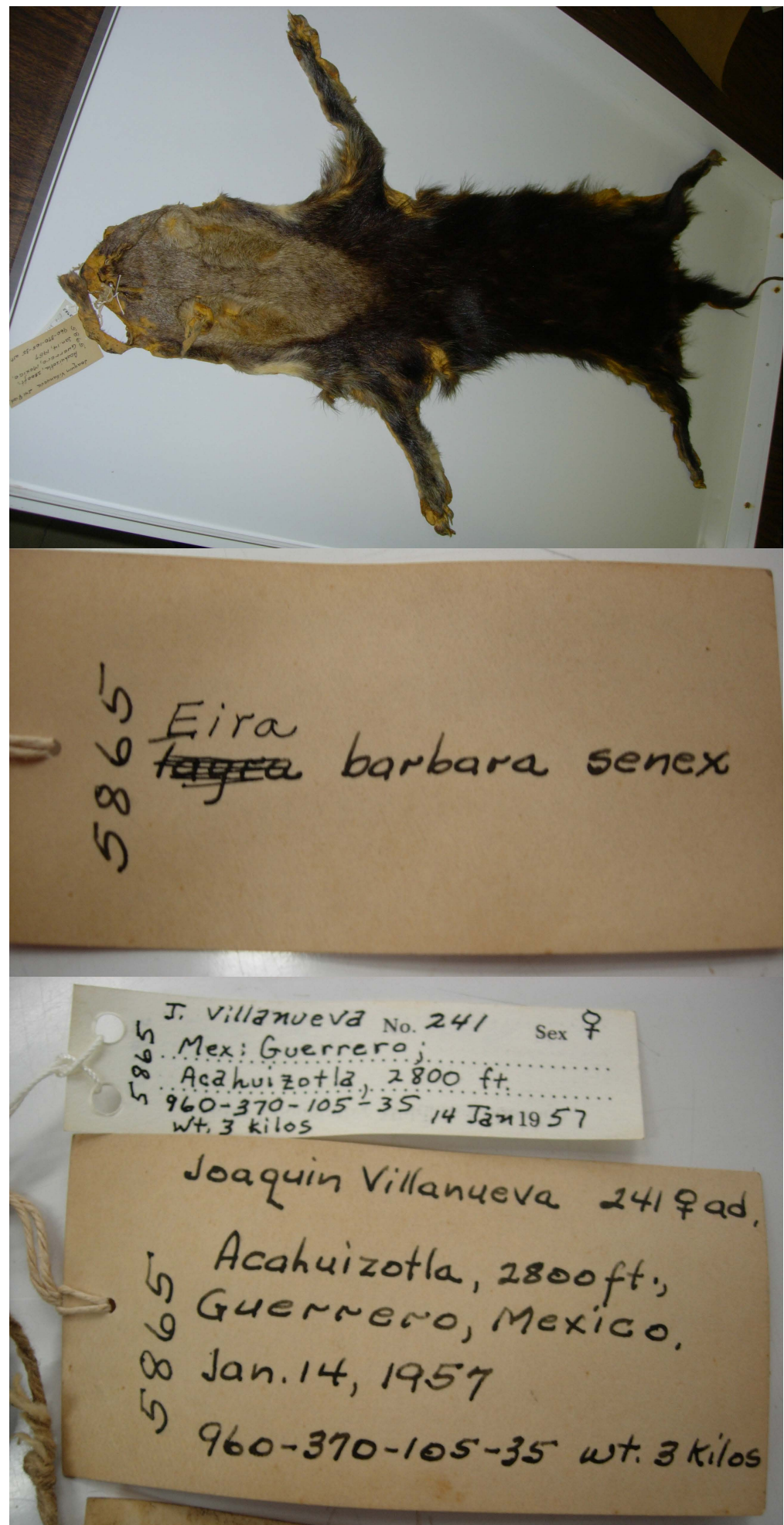

Fig. 3. Top panel: An individual of E. barbara deposited in the Texas Cooperative Wildlife Collection (TCWC), Department of Wildlife and Fisheries Sciences, Texas A\&M University. Middle and bottom panels: Original specimen labels. 
latter sites due to the high availability of fruit trees and small vertebrates. However, the tayra is rarely found outside the forest due to its arboreal tendencies (Presley 2000). Other carnivore species detected at the tayra localities are margay (Leopardus wiedii), jaguarondi (Puma yagouaroundi), puma (Puma concolor), jaguar (Panthera onca), gray fox (Urocyon cinereoargenteus), weasel (Mustela frenata), and white-nosed coati (Nasua narica).

The camera trapping conducted in this study contributes significantly to the basic information on the distribution of E. barbara. In the short term, an assessment of the tayra's population status in Guerrero could be implemented due to the distinct markings of individuals in the study population. The assessment would be especially relevant, because land use changes are occurring at all the sites where records were found.

We thank the people and authorities of the study area communities and ejidos for their hospitality and for permission to conduct research on their land. We are grateful to Fernando Cervantes, Yolanda Hortelano, and Julieta Vargas of the Colección Nacional de Mamíferos (= National Collection of Mammals), Instituto de Biología, UNAM, for their help in the review and curation of specimens. We also thank the staff of the Instituto de Ecología, UNAM, who supported the research team for camera trapping, and the Universidad Autónoma de Guerrero for all the support in carrying out the sampling. Thanks to biologists Luis Flores, Alemi Nava, and Adriana J. Fuentes, who contributed to the generation of information; also thanks to Pilar Rueda Zozaya, J.J. Figuel, and Evelyn Piña for the comments made on this note. Photographs of Eira barbara and labels were courtesy of B.D. Marks, Curator of Birds and Mammals, Texas Cooperative Wildlife Collection, Department of Wildlife and Fisheries Sciences, Texas A\&M University.

\section{Literature Cited}

Allen, J.A. 1906. Mammals from the states of Sinaloa and Jalisco, Mexico, collected by J.H. Batty during 1904 and 1905. Bulletin of the American Museum of Natural History 22:191-262.

Álvarez-Castañeda, S.T. 2000. Familia Mustelidae. Mamíferos del Noroeste de México II. Centro de Investigaciones Biológicas del Noroeste, S.C. 12: 587-873.

BRooks, D.M. 1993. Distribution, habitat association, and factors determining assemblage composition of mam- mals in the Paraguayan Chaco. Doctoral thesis, Texas Tech University, Lubbock, TX.

Chávez, C. 2014. Tayra (Eira barbara). In: G. Ceballos, editor, Mammals of Mexico. John Hopkins University Press, Baltimore, MD.

Cruz-Espinoza, A., G.E. GonzÁlez-PÉrez, And P. RonelVÁzQuez. 2012. Nota de la variación en la riqueza específica de mamíferos entre áreas de conservación y de aprovechamiento forestal en la Sierra Madre de Oaxaca. Therya 3:327-332.

Emmons, L.H., AND F. FreER. 1990. Neotropical rainforest mammals: field guide. University of Chicago Press, Chicago, IL.

Espinosa-Lucas, A., A. Méndez, O. Hernández, A. Flores-Cortez, F. Botello, and I. Mariscal. 2015. Tres nuevos registros en la zona de influencia de la Reserva de la Biosfera Tehuacán-Cuicatlán, Oaxaca. Therya 6:661-666.

Godínez, E.G., N. GonzÁlez-Ruiz, and J. RamírezPulido. 2011. Actualización de la lista de los mamíferos de Jalisco, México: implicaciones de los cambios taxonómicos. Therya 2:7-35.

Hall, E.R., and K.R. Kelson. 1959. The mammals of North America. 2 volumes. The Ronald Press Co., New York, NY. 1083 pp.

Lira-Torres, I., AND M. Briones-SALAs. 2012. Abundancia relativa y patrones de actividad de los mamíferos de los Chimalapas, Oaxaca, México. Acta Zoológica Mexicana 28:566-585.

López González, C., AND D. Aceves. 2007. Noteworthy record of the tayra (Carnivora: Mustelidae: Eira barbara) in the Sierra Gorda Biosphere Reserve, Querétaro, México. Western North American Naturalist 67:150-151.

López-Wilchis, R., and J. López-Jardines. 1999. Los mamíferos de México depositados en colecciones de Estados Unidos y Canadá, Volumen II. Universidad Autónoma Metropolitana-Unidad Iztapalapa, Distrito Federal, México.

Monterrubio-Rico, T.C., J.F.C. Medellín, C.Z. ColínSoto, and L.L. Paniagua. 2014. Los mamíferos de Michoacán. Revista Mexicana de Mastozoología (Nueva Época) 4:1-17.

Official Journal of the Federation. 2010. NOM-059SEMARNAT-2010. Norma Oficial Mexicana. Protección Ambiental-Especies Nativas de México de Flora y Fauna Silvestres-Categorías de Riesgo y Especificaciones para su Inclusión, Exclusión o Cambio-Lista de Especies en Riesgo. Diario Oficial de la Federación. 30 de Diciembre de 2010. Distrito Federal, México. 78 pp.

Pérez-Irineo, G., AND A. Santos-Moreno. 2010. Diversidad de una Comunidad de Mamíferos Carnívoros, en una selva Mediana del Norte de Oaxaca, México. Acta Zoológica Mexicana 26:721-736.

Presley, S.J. 2000. Eira barbara. Mammalian Species 636:1-6.

Werre, K.F., and G. Estrada. 1999. Monografía GeológicoMinera del Estado de Guerrero. Consejo de Recursos Minerales, Secretaría de Comercio y Fomento Industrial, Distrito Federal, México.

Received 19 October 2016 Accepted 16 May 2017

Published online 29 September 2017 